\title{
ANALIZA DRGAŃ WIESZARA CIĘGNOWEGO JAKO MODELU KOLEJOWEJ SIECI TRAKCYJNEJ OBCIĄŻONEJ RUCHEM PANTOGRAFÓW
}

\begin{abstract}
Zwiększenie prędkości jazdy pociągów i rozwój kolei dużych prędkości spowodowały wyraźny wzrost zainteresowania problemami dynamiki kolejowych sieci trakcyjnych. W ostatnich latach pojawiło się w literaturze zagranicznej wiele nowych publikacji przedstawiających zaawansowane numerycznie metody symulacji drgań górnej sieci jezdnej i pantografów. W Polsce temat ten jest stosunkowo mało znany, stąd jednym z celów pracy jest przegląd literatury na temat metod modelowania sieci trakcyjnych. Celem zasadniczym jest przedstawienie oryginalnej metody symulacji drgań sprzężonego układu sieć trakcyjna - pantograf oraz zastosowanie metody do analizy drgań przykładowej sieci trakcyjnej. Metoda bazuje na modelu obliczeniowym przedstawionym przez autorów w odrębnej pracy, sformułowanym na podstawie teorii drgań wiotkiego cięgna z ciągłym rozkładem masy. Górna sieć jezdna jest traktowana jako wstępnie napięty, wieloprzęsłowy wieszar cięgnowy złożony z liny nośnej o niepomijalnym zwisie w przęsłach i przewodu jezdnego podwieszonego za pomocą wiotkich wieszaków nie przenoszących ściskania. Sieć trakcyjna jest obciążona dwoma pantografami poruszającymi się ze stałą prędkością. Pantografy są układami dynamicznymi o dwóch stopniach swobody. Równania ruchu wyprowadzone metodą Lagrange'a - Ritza zostały w tej pracy przekształcone poprzez wyodrębnienie nieliniowych sił, które kompensują wpływ wieszaków ściskanych. Opisano metodę rozwiązania nieliniowych równań ruchu i wyjaśniono sens fizyczny stowarzyszonych z nimi równań liniowych. Przedstawiono przykład symulacji drgań sieci złożonej z dziesięciu przęseł, świadczący o efektywności i możliwościach obliczeniowych prezentowanej metody oraz zbadano wpływ tłumienia w materiale liny nośnej i przewodu jezdnego na charakterystyki dynamiczne badanej sieci.
\end{abstract}

Słowa kluczowe: symulacja drgań, drgania liniowe, drgania nieliniowe, siła nacisku stykowego, drgania przewodu jezdnego, wpływ tłumienia

\footnotetext{
1 Autor do korespondencji / corresponding author: Danuta Bryja, Politechnika Wrocławska, Katedra Mostów i Kolei, Wybrzeże St. Wyspiańskiego 27, 50-370 Wrocław; tel. 713202332; danuta.bryja@pwr.edu.pl

2 Adam Popiołek, Politechnika Wrocławska, Katedra Mostów i Kolei, Wybrzeże St. Wyspiańskiego 27, 50-370 Wrocław; tel. 713204469; adam.popiolek@pwr.edu.pl
} 


\section{Wprowadzenie}

Kolejowa sieć trakcyjna, a mówiąc ściślej, górna sieć jezdna stała się obiektem zainteresowań specjalistów z dziedziny dynamiki konstrukcji w związku ze wzrostem prędkości jazdy pociągów i pojawieniem się kolei dużych prędkości. Obecnie, silnym bodźcem rozwoju badań problemów dynamiki sieci jezdnych jest prawo wdrażające na obszarze Unii Europejskiej zasady interoperacyjności w zakresie rynku kolejowego [1]. Jednym z jego wymagań jest ocena tzw. charakterystyki dynamicznej górnej sieci jezdnej. Ocena ta odbywa się na podstawie analizy zmian siły nacisku stykowego (nacisku ślizgacza pantografu na przewód jezdny) oraz pionowych drgań przewodu jezdnego na wspornikach sieci. Dodatkowo analizuje się jakość odbioru prądu, którego miarą jest tzw. procent utraty kontaktu, utożsamiany z udziałem czasu, w którym siła nacisku stykowego jest ujemna - w całkowitym czasie przejazdu pantografu przez badany odcinek sieci.

Analizowane wielkości dynamiczne mogą być wyznaczane eksperymentalnie lub za pomocą symulacji numerycznych. Wobec dużych kosztów i nakładu pracy niezbędnych do wykonania badań eksperymentalnych, symulacje numeryczne są korzystniejsze $\mathrm{w}$ zastosowaniach inżynierskich, gdy zachodzi konieczność częstego wykonywania ocen parametrów sieci. W Polsce, podstawowym problemem w tym zakresie jest ograniczony dostęp do odpowiedniego oprogramowania. $\mathrm{Z}$ tego powodu, w ośrodku wrocławskim podjęto badania ukierunkowane na poszukiwania efektywnych modeli numerycznych i algorytmów obliczeniowych, które dawałyby wiarygodne wyniki przy akceptowalnym czasie wykonywania symulacji. W pierwszym etapie badań przeprowadzono obszerne studia literaturowe, a następnie, bazując na doświadczeniach innych autorów, zaproponowano w pracy [2] oryginalny model numeryczny górnej sieci jezdnej, traktowanej jako złożony wieszar cięgnowy obciążony przejazdem dwóch pantografów, przy czym każdy z nich jest modelowany układem o dwóch dynamicznych stopniach swobody. Zasadniczym celem niniejszej pracy jest:

- przedstawienie metody symulacji drgań sieci trakcyjnej, spowodowanych ruchem pantografów,

- zastosowanie metody do analizy drgań przykładowej sieci, w aspekcie oceny wpływu tłumienia materiałowego w linie nośnej i przewodzie jezdnym.

Treść merytoryczną pracy poprzedzono przeglądem literatury na temat metod modelowania i symulacji drgań kolejowych sieci trakcyjnych.

\section{Przegląd metod modelowania i symulacji drgań układu pantograf - sieć trakcyjna}

W literaturze światowej można znaleźć opisy wielu badań w zakresie dynamiki górnej sieci jezdnej, w tym sformułowania różnych modeli obliczeniowych układu pantograf - sieć trakcyjna. Obszerny przegląd badań prowadzonych w tym zakresie do 1997 roku przedstawili Poetsch i in. [3]. Stwierdzili oni 
między innymi, że istotne znaczenie ma opis sposobu rozchodzenia się fali drgań w przewodzie jezdnym, zależny od przyjętej metody modelowania. Kluczową rolę odgrywa tu sztywność giętna przewodu jezdnego, która jest uwzględniana w modelu prętowym, a nie występuje w modelu cięgnowym. Wpływa ona istotnie na wyniki analiz zjawisk wysokoczęstotliwościowych, nie ma natomiast dużego wpływu na drgania w zakresie niskich częstotliwości. W pracy [3] poświęcono wiele uwagi kwestii modelowania pantografów. Przedstawiono zarówno uproszczone modele dwuwymiarowe jak i bogatsze modele trójwymiarowe, w odniesieniu do rzeczywistych konstrukcji odbieraków prądowych.

Współcześnie stosowane są trzy grupy metod modelowania układu pantograf - sieć trakcyjna. Pierwsza z nich to modele uproszczone, przeznaczone do analizy drgań pantografów, pomijające wzajemne oddziaływania dynamiczne sieci trakcyjnej i pantografu. Przykładem tego podejścia jest praca Wu i Brennana [4], którzy zaproponowali model o jednym dynamicznym stopniu swobody, w którym element masowy odpowiada masie całego pantografu a sieć jezdna sprowadzona jest do więzi sprężystej o zmiennej sztywności. Sztywność więzi zmienia się w czasie symulując ruch pantografu wzdłuż sieci. Jest wyznaczana w sposób statyczny, z wykorzystaniem metody elementów skończonych do modelowania sieci jezdnej. W kolejnej pracy [5], Wu i Brennan rozbudowali model zastępując sztywność statyczną więzi sprężystej tzw. sztywnością dynamiczną, która wyznaczana jest na podstawie analizy drgań wieloprzęsłowej struny o ciągłym rozkładzie masy, stałym naciągu i podparciu punktowym za pomocą więzi sprężystych. Struna obciążona jest pojedynczą siłą ruchomą o stałej wartości. Park $i$ in. [6] zastosowali model odbieraka o trzech stopniach swobody, zastępując sieć trakcyjną więzią sprężystą o zmiennej sztywności, podobnie jak w pracach Wu i Brennana. Sztywność więzi wyznaczyli metodą elementów skończonych, w węzłach siatki podziału przewodu jezdnego na elementy, a następnie przybliżyli rozkład sztywności funkcją trygonometryczną. Za model sieci trakcyjnej przyjęli układ dwóch belek reprezentujących linę nośną i przewód jezdny, połączonych więziami sprężystymi zastępującymi wieszaki. W pracy [7] wprowadzono uproszczony model dynamiczny sieci trakcyjnej w postaci oscylatora lepko-sprężystego ze zmienną sztywnością oraz tłumieniem, które mają symulować parametry sieci zmieniające się wraz z ruchem pantografu. Pantograf jest modelowany układem o dwóch dynamicznych stopniach swobody.

Druga grupa modeli układu pantograf - sieć trakcyjna to zaawansowane numerycznie modele sieci trakcyjnej jako układu z ciągłym rozkładem masy oraz sprzężonego z nim pantografu w postaci układu dyskretnego. Tego typu model zastosowali m.in. Arnold i Simeon [8], przyjmując, że lina nośna sieci jezdnej jest cięgnem a przewód jezdny belką Eulera. Wieszaki potraktowali jako wiotkie elementy typu przewodowego, z uwzględnieniem nieliniowego zachowania polegającego na nieprzenoszeniu ściskania. Model pantografu przyjęto w postaci układu o dwóch stopniach swobody, w którym elementy masowe odpowiadają masom ślizgacza oraz ramy przegubowej. Cząstkowe różniczkowe 
równania ruchu rozwiązywali numerycznie - metodą MOL (metodą linii) z dyskretyzacją przestrzenną różnicami skończonymi. Podobne podejście zastosował Cho [9] przyjmując model sieci trakcyjnej złożony z dwóch belek Eulera obciążonych stałymi siłami poziomymi, które symulują wstępny naciąg sieci. Wieszaki łączące przewód jezdny z liną nośną są modelowane więziami sprężysto-tłumiącymi. W każdym kroku symulacji sprawdzano wartości sił wewnętrznych w wieszakach, po czym zerowano składniki macierzy sztywności i tłumienia, odpowiadające wieszakom ściskanym.

Trzecia grupa metod modelowania układu sieć trakcyjna - pantograf wykorzystuje metodę symulacji równoległej. Polega ona na zastosowaniu oddzielnych programów obliczeniowych do symulacji drgań sieci jezdnej i pantografu oraz określonego schematu komunikacji pomiędzy nimi. Sieć jest modelowana metodą elementów skończonych, a pantograf jest modelem dyskretnym o wielu stopniach swobody. Program odpowiadający za symulację drgań pantografu przekazuje w każdym kroku obliczeniowym dane na temat pozycji oraz parametrów drgań ślizgacza do programu symulującego drgania sieci. W tej części oprogramowania wyznaczana jest siła nacisku stykowego, która następnie przekazywana jest zwrotnie do modelu pantografu. Metoda ta wykorzystana została m.in. przez Rauter'a i in. w pracy [10]. Pombo i Ambrósio [11] zastosowali ją do analizy wpływu wiatru i nierówności toru na dynamiczną siłę interakcji między pantografem a siecią. Drgania nadwozia pojazdu, wyznaczone za pomocą zaawansowanego modelu układu tor - pojazd, uwzględniono jako wymuszenie kinematyczne drgań pantografu. Do modelowania wszystkich elementów górnej sieci jezdnej (liny nośnej, przewodu jezdnego i wieszaków) zastosowano elementy prętowe typu Eulera. W każdym kroku symulacji drgań przeprowadzano korektę równań ruchu poprzez wprowadzenie sił kompensacyjnych powodujących wyłączenie wieszaków ściskanych. Artykuł Pombo i Ambrósio [11] jest jedną z niewielu prac, w których badano wpływ obciążenia dwoma pantografami.

Metoda symulacji równoległej umożliwia szczegółowe modelowanie pantografów w zaawansowanym oprogramowaniu do analizy układów dyskretnych, co pozwala na analizy w kierunku optymalizacji konstrukcji odbieraków [12].

\section{Metoda symulacji numerycznej drgań sieci trakcyjnej}

Przedstawiana w artykule metoda symulacji drgań sieci trakcyjnej bazuje na modelu obliczeniowym układu sieć trakcyjna - pantograf, sformułowanym w pracy [2]. Model ten odnosi się do górnej sieci jezdnej typu łańcuchowego, pokazanej schematycznie na rys.1. Sieć składa się z wieloprzęsłowej, wstępnie napiętej liny nośnej o niepomijalnym zwisie w przęsłach oraz wstępnie napiętego przewodu jezdnego, podwieszonego do liny za pośrednictwem wieszaków typu przewodowego, czyli nie przenoszących ściskania. Lina nośna jest zakotwiona na końcach wieloprzęsłowego odcinka naprężania sieci, podobnie jak przewód jezdny. 


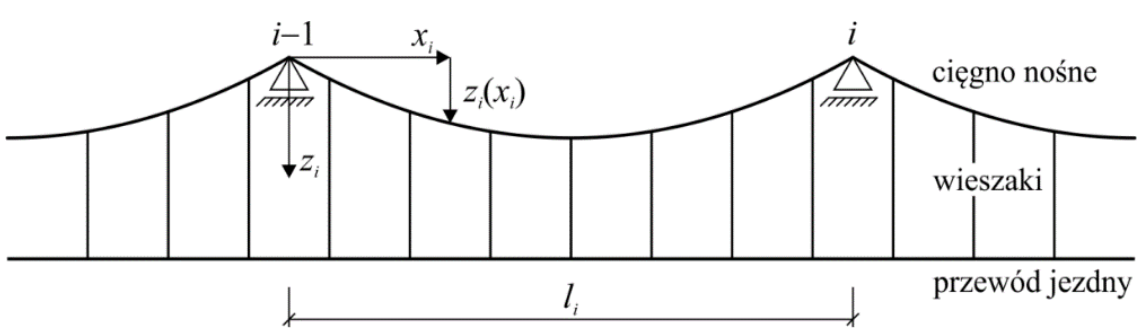

Rys. 1. Schemat górnej sieci jezdnej kolejowej trakcji elektrycznej

Fig. 1. Scheme of a railway overhead wire system

Specyficzną i oryginalną cechą modelu obliczeniowego zaproponowanego w pracy [2] jest konsekwentne zastosowanie teorii drgań ciągłego cięgna do modelowania górnej sieci jezdnej jako złożonego wieszara cięgnowego. Modelem fizycznym liny nośnej jest liniowo-sprężyste cięgno wiotkie o ciągłym rozkładzie masy, oparte przesuwnie na sztywnych podporach. Modelem przewodu jezdnego jest liniowo-sprężysta struna o masie rozłożonej w sposób ciągły, podwieszona do wieloprzęsłowego cięgna za pomocą więzi sprężystych o jednakowych sztywnościach - niezerowych, jeśli więzi są rozciągane i zerowych przy ściskaniu. Sieć jezdna jest obciążona dwo-

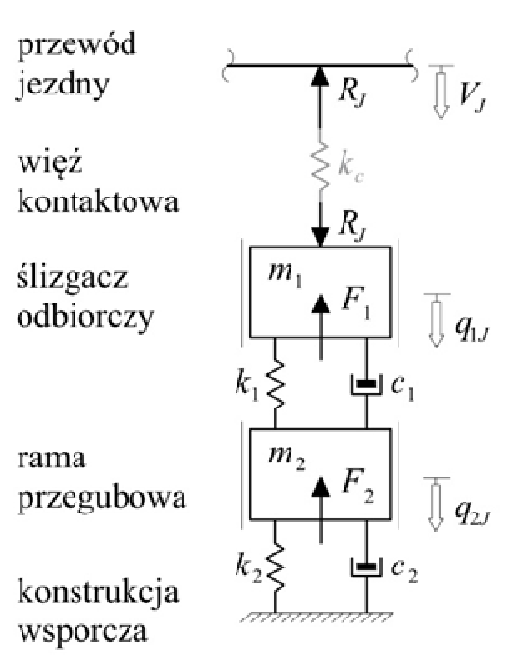

Rys. 2. Model dynamiczny pantografu

Fig. 2. Dynamic model of the pantograph ma pantografami poruszającymi się ze stałą prędkością.

$\mathrm{Na}$ rys. 2 przedstawiono model dynamiczny pantografu przyjęty w postaci układu dyskretnego o dwóch stopniach swobody, który składa się z dwóch mas reprezentujących ślizgacz odbiorczy i ramę przegubową. Masy są połączone ze sobą i z konstrukcją wsporczą (pojazdem) układem więzi sprężystych i thumiących. Dodatkowo wprowadzono tzw. sprężynę kontaktową między ślizgaczem odbiorczym i punktem styku nakładki stykowej $\mathrm{z}$ przewodem jezdnym. Zmienna w czasie reakcja więzi kontaktowej $R_{J}(t)$ jest równocześnie siłą nacisku stykowego ślizgacza, złożoną ze stałej siły statycznej i dynamicznego przyrostu spowodowanego drganiami sieci jezdnej i pantografu w trakcie jego przejazdu wzdłuż analizowanego odcinka sieci. Indeks $J=$ I, II oznacza tu numer pantografu. Pokazane na rys. 2 siły $F_{1}$ i $F_{2}$, wynikające z działania urządzenia podnoszącego pantograf, tworzą łącznie statyczną siłę nacisku stykowego ślizgacza na przewód jezdny. 
Równania ruchu przyjętego modelu układu sieć trakcyjna - pantografy zostały wyprowadzone $\mathrm{w}$ pracy [2] z zastosowaniem metody aproksymacyjnej Lagrange'a - Ritza. Przedstawiono je w następującej postaci blokowo-macierzowej

$$
\begin{aligned}
& {\left[\begin{array}{ccc}
\mathbf{B}_{\mathrm{cc}} & \mathbf{0} & \mathbf{0} \\
\mathbf{0} & \mathbf{B}_{\mathrm{pp}} & \mathbf{0} \\
\mathbf{0} & \mathbf{0} & \mathbf{B}_{\mathrm{oo}}
\end{array}\right]\left[\begin{array}{c}
\ddot{\mathbf{q}}_{\mathrm{c}}(t) \\
\ddot{\mathbf{q}}_{\mathrm{p}}(t) \\
\ddot{\mathbf{q}}_{\mathrm{o}}(t)
\end{array}\right]+\left[\begin{array}{ccc}
\mathbf{C}_{\mathrm{cc}} & \mathbf{0} & \mathbf{0} \\
\mathbf{0} & \mathbf{C}_{\mathrm{pp}} & \mathbf{0} \\
\mathbf{0} & \mathbf{0} & \mathbf{C}_{\mathrm{oo}}
\end{array}\right]\left[\begin{array}{c}
\dot{\mathbf{q}}_{\mathrm{c}}(t) \\
\dot{\mathbf{q}}_{\mathrm{p}}(t) \\
\dot{\mathbf{q}}_{\mathrm{o}}(t)
\end{array}\right]+} \\
& {\left[\begin{array}{ccc}
\left(\mathbf{K}_{\mathrm{cc}}+\hat{\mathbf{K}}_{\mathrm{cc}}\right) & -\hat{\mathbf{K}}_{\mathrm{cp}} & \mathbf{0} \\
-\hat{\mathbf{K}}_{\mathrm{pc}} & \left(\tilde{\mathbf{K}}_{\mathrm{pp}}+\hat{\mathbf{K}}_{\mathrm{pp}}+\tilde{\mathbf{K}}_{\mathrm{pp}}(t)\right) & -\tilde{\mathbf{K}}_{\mathrm{po}}(t) \\
\mathbf{0} & -\tilde{\mathbf{K}}_{\mathrm{op}}(t) & \mathbf{K}_{\mathrm{oo}}
\end{array}\right]\left[\begin{array}{c}
\mathbf{q}_{\mathrm{c}}(t) \\
\mathbf{q}_{\mathrm{p}}(t) \\
\mathbf{q}_{\mathrm{o}}(t)
\end{array}\right]=\left[\begin{array}{c}
\mathbf{0} \\
\tilde{\mathbf{F}}_{\mathrm{p}}(t) \\
\mathbf{0}
\end{array}\right]}
\end{aligned}
$$

która sprowadza się do powszechnie znanego równania macierzowego

$$
\mathbf{B} \ddot{\mathbf{q}}(t)+\mathbf{C} \dot{\mathbf{q}}(t)+\mathbf{K}(t) \mathbf{q}(t)=\mathbf{f}(t)
$$

stanowiącego układ równań różniczkowych zwyczajnych II rzędu o zmiennych w czasie współczynnikach. Warto zauważyć, że dzięki zastosowaniu więzi kontaktowej współczynniki zależne od czasu są zgrupowane tylko w niektórych blokach macierzy sztywności, oznaczonych w równaniu (1) nadpisaną tyldą. Bloki oznaczone daszkiem zależą od sztywności więzi sprężystych (wieszaków) łączących linę nośną z przewodem jezdnym. Wszystkie oznaczenia użyte w równaniu (1) a także definicje bloków macierzy bezwładności, tłumienia i sztywności oraz wektora wzbudzania można odtworzyć na podstawie pracy [2].

Zasadniczym elementem metody symulacji drgań jest rozwiązanie równania ruchu (2) o strukturze blokowej (1). Równanie to jest w istocie nieliniowe, ponieważ sztywności wieszaków zależą od stanu przemieszczenia wieszara cięgnowego. Zależność ta nie ma postaci jawnej, bowiem sztywność każdego wieszaka $k_{\mathrm{w}}$ jest zdefiniowana warunkowo relacjami

$$
k_{\mathrm{w}}=\left\{\begin{array}{lll}
k & \text { gdy } & w_{\text {liny }} \leq v_{\text {przewodu }} \\
0 & \text { gdy } & w_{\text {liny }}>v_{\text {przewodu }}
\end{array}\right.
$$

gdzie symbolami $w_{\text {liny }}$ i $v_{\text {przewodu }}$ oznaczono zależne od czasu pionowe przemieszczenie liny nośnej i przewodu jezdnego w miejscu mocowania wieszaka.

Aby sformułować metodę rozwiązania nieliniowego równania ruchu (2), rozdzielono macierz sztywności $\mathbf{K}(t)$ na cztery składniki według wzoru

$$
\mathbf{K}(t)=\mathbf{K}_{\text {const }}+\hat{\mathbf{K}}_{\text {const }}-\hat{\mathbf{K}}_{\mathrm{ws}}\left(\mathbf{q}_{\mathrm{c}}, \mathbf{q}_{\mathrm{p}}\right)+\tilde{\mathbf{K}}(t)
$$

gdzie, jak wynika ze struktury równania (1), stałe składniki macierzy sztywności 
mają postać: $\mathbf{K}_{\text {const }}=\left[\begin{array}{ccc}\mathbf{K}_{\mathrm{cc}} & \mathbf{0} & \mathbf{0} \\ \mathbf{0} & \mathbf{K}_{\mathrm{pp}} & \mathbf{0} \\ \mathbf{0} & \mathbf{0} & \mathbf{K}_{\mathrm{oo}}\end{array}\right], \hat{\mathbf{K}}_{\mathrm{const}}=\left[\begin{array}{ccc}\hat{\mathbf{K}}_{\mathrm{cc}} & -\hat{\mathbf{K}}_{\mathrm{cp}} & \mathbf{0} \\ -\hat{\mathbf{K}}_{\mathrm{pc}} & \hat{\mathbf{K}}_{\mathrm{pp}} & \mathbf{0} \\ \mathbf{0} & \mathbf{0} & \mathbf{0}\end{array}\right]$, a składnik zależny od czasu: $\quad \tilde{\mathbf{K}}(t)=\left[\begin{array}{ccc}\mathbf{0} & \mathbf{0} & \mathbf{0} \\ \mathbf{0} & \tilde{\mathbf{K}}_{\mathrm{pp}}(t) & -\tilde{\mathbf{K}}_{\mathrm{po}}(t) \\ \mathbf{0} & -\tilde{\mathbf{K}}_{\mathrm{op}}(t) & \mathbf{0}\end{array}\right]$. Stały składnik $\hat{\mathbf{K}}_{\text {const }}$ wynika z niezerowej sztywności wyjściowej $k$ wszystkich wieszaków, natomiast składnik $\hat{\mathbf{K}}_{\text {ws }}\left(\mathbf{q}_{\mathrm{c}}, \mathbf{q}_{\mathrm{p}}\right)$, chociaż ma ogólną strukturę identyczną jak $\hat{\mathbf{K}}_{\text {const }}$, to dotyczy wyłącznie wieszaków ściskanych - kompensuje (zeruje) ich wpływ w globalnej macierzy sztywności, co jest równoznaczne z przyjęciem, że sztywności wieszaków ściskanych są zerowe. Składnik kompensacyjny macierzy sztywności, $\hat{\mathbf{K}}_{\mathrm{ws}}\left(\mathbf{q}_{\mathrm{c}}, \mathbf{q}_{\mathrm{p}}\right)$, jest zależny od współrzędnych uogólnionych określających stan przemieszczenia liny nośnej $\left(\mathbf{q}_{\mathrm{c}}\right)$ i przewodu jezdnego $\left(\mathbf{q}_{\mathrm{p}}\right)$, ponieważ są one wykorzystywane w każdej chwili $t$ do identyfikacji wieszaków ściskanych.

Po podstawieniu relacji (4) i przeniesieniu składnika nieliniowego na prawą stronę, równanie (2) przyjmuje następującą postać

$$
\mathbf{B} \ddot{\mathbf{q}}(t)+\mathbf{C} \dot{\mathbf{q}}(t)+\left[\mathbf{K}_{\text {const }}+\hat{\mathbf{K}}_{\text {const }}+\tilde{\mathbf{K}}(t)\right] \mathbf{q}(t)=\mathbf{f}(t)+\hat{\mathbf{K}}_{\mathrm{ws}}\left(\mathbf{q}_{\mathrm{c}}, \mathbf{q}_{\mathrm{p}}\right) \mathbf{q}(t)
$$

Nieliniowy składnik równania (5) opisuje siły kompensujące wpływ wieszaków ściskanych, zależne od współrzędnych uogólnionych, co można zapisać wzorem

$$
\mathbf{f}_{\mathrm{nl}}(\mathbf{q})=\hat{\mathbf{K}}_{\mathrm{ws}}\left(\mathbf{q}_{\mathrm{c}}, \mathbf{q}_{\mathrm{p}}\right) \mathbf{q}(t)
$$

Łatwo zauważyć, że pominięcie tych sił prowadzi do liniowego równania ruchu. Równanie liniowe opisuje sprzężone drgania pantografów i wieszara cięgnowego, w którym wieszaki są więziami liniowo-sprężystymi o stałej niezerowej sztywności $k$, przenoszącymi zarówno rozciąganie jak i ściskanie.

Rozwiązanie układu równań ruchu (5) uzyskuje się numerycznie. W pracy zastosowano bezwarunkowo stabilny wariant metody Newmarka, przy czym typowy schemat rekurencyjny metody uzupełniono w każdym kroku całkowania procedurą iteracyjną prowadzącą do wyznaczenia wektora sił nieliniowych $\mathbf{f}_{\mathrm{nl}}(\mathbf{q})$ z zadaną dokładnością.

Na podstawie rozwiązania $\mathbf{q}(t)$ obliczanego sukcesywnie w kolejnych punktach czasowych wynikających z przyjętego kroku całkowania $h$, wyznacza się przebiegi drgań w dowolnym punkcie liny nośnej i przewodu jezdnego oraz drgań pantografów a także przebiegi dynamicznych zmian siły nacisku stykowego. Odpowiednie formuły obliczeniowe można znaleźć w pracy [2]. 


\section{Symulacja drgań przykładowej sieci trakcyjnej}

Aby zademonstrować możliwości obliczeniowe opisanej metody symulacyjnej, poddano analizie przykładową sieć jezdną złożoną z dziesięciu przęseł, obciążoną ruchem jednego pantografu. Charakterystyki geometryczne i materiałowe elementów sieci trakcyjnej oraz parametry pantografu podano w tab. 1 . Dane te przyjęto na podstawie specyfikacji tzw. modelu odniesienia, opisanego w załączniku A normy EN 50318: 2002 [13], która określa wymagania jakie powinna spełniać metoda symulacji oddziaływania dynamicznego pomiędzy pantografem a górną siecią jezdną.

Na podstawie danych sieci obliczono podstawową częstość własną liny nośnej $\left(\omega_{\mathrm{c}}=6,36 \mathrm{rad} / \mathrm{s}\right)$ i przewodu jezdnego $\left(\omega_{\mathrm{p}}=0,64 \mathrm{rad} / \mathrm{s}\right)$, traktowanych niezależnie. Uwzględniono tłumienie $\mathrm{w}$ materiale liny nośnej i przewodu jezdnego, przyjmując, że $\mathbf{C}_{\mathrm{cc}}=\kappa_{\mathrm{c}} \mathbf{K}_{\mathrm{cc}}$ oraz $\mathbf{C}_{\mathrm{pp}}=\kappa_{\mathrm{p}} \mathbf{K}_{\mathrm{pp}}$ (por. równanie (1)), przy czym czasy retardacji obliczono według relacji: $\kappa_{\mathrm{c}}=2 \alpha_{\mathrm{c}} / \omega_{\mathrm{c}}, \kappa_{\mathrm{p}}=2 \alpha_{\mathrm{p}} / \omega_{\mathrm{p}}$. Wartości liczb tłumienia $\alpha_{\mathrm{c}}$ i $\alpha_{\mathrm{p}}$ wariantowano w granicach od 0 do $5 \%$.

Tabela 1. Charakterystyki geometryczne i materiałowe elementów sieci trakcyjnej oraz parametry pantografów, na podstawie [13]

Table 1. Geometrical and material properties of the railway overhead wire system and pantograph parameters, based on [13]

\begin{tabular}{|l|c|l|c|}
\hline Masa jednostkowa liny nośnej & $1,07 \mathrm{~kg} / \mathrm{m}$ & Prędkość pantografu & $300 \mathrm{~km} / \mathrm{h}$ \\
\hline Naciąg liny nośnej & $16 \mathrm{kN}$ & Masa ślizgacza pantografu & $7,2 \mathrm{~kg}$ \\
\hline Sztywność osiowa liny nośnej & $12 \mathrm{MN}$ & Masa ramy pantografu & $15,0 \mathrm{~kg}$ \\
\hline $\begin{array}{l}\text { Masa jednostkowa przewodu } \\
\text { jezdnego }\end{array}$ & $1,35 \mathrm{~kg} / \mathrm{m}$ & $\begin{array}{l}\text { Siła nacisku statycznego } \\
\text { pantografu }\end{array}$ & $120 \mathrm{~N}$ \\
\hline Naciąg przewodu jezdnego & $20 \mathrm{kN}$ & $\begin{array}{l}\text { Sztywność górnej sprężyny } \\
\text { pantografu }\left(k_{1}\right)\end{array}$ & $4200 \mathrm{~N} / \mathrm{m}$ \\
\hline $\begin{array}{l}\text { Sztywność wieszaka przy } \\
\text { rozciąganiu }\end{array}$ & $100 \mathrm{kN} / \mathrm{m}$ & $\begin{array}{l}\text { Sztywność dolnej sprężyny } \\
\text { pantografu }\left(k_{2}\right)\end{array}$ & $50 \mathrm{~N} / \mathrm{m}$ \\
\hline Długość przęsła & $60 \mathrm{~m}$ & $\begin{array}{l}\text { Parametr górnego tłumika } \\
\text { pantografu }\left(c_{1}\right)\end{array}$ & $10 \mathrm{Ns} / \mathrm{m}$ \\
\hline Liczba przęseł & 10 & $\begin{array}{l}\text { Parametr dolnego tłumika } \\
\text { pantografu }(c 2)\end{array}$ & $90 \mathrm{Ns} / \mathrm{m}$ \\
\hline Liczba wieszaków w przęśle & 9 & $\begin{array}{l}\text { Sztywność sprężyny kontak- } \\
\text { towej }\left(k_{c}\right)\end{array}$ & $50 \mathrm{kN} / \mathrm{m}$ \\
\hline
\end{tabular}

Obliczenia, których wyniki pokazano w pracy, dotyczą głównie problemu liniowego, czyli analizowany jest wieszar cięgnowy z wieszakami przenoszącymi zarówno rozciąganie jak i ściskanie. Rozwiązania zagadnienia nieliniowego 
będą obszernie analizowane w odrębnej publikacji, natomiast w tej pracy będzie pokazany poglądowy przykład porównania rozwiązań nieliniowych z liniowymi.
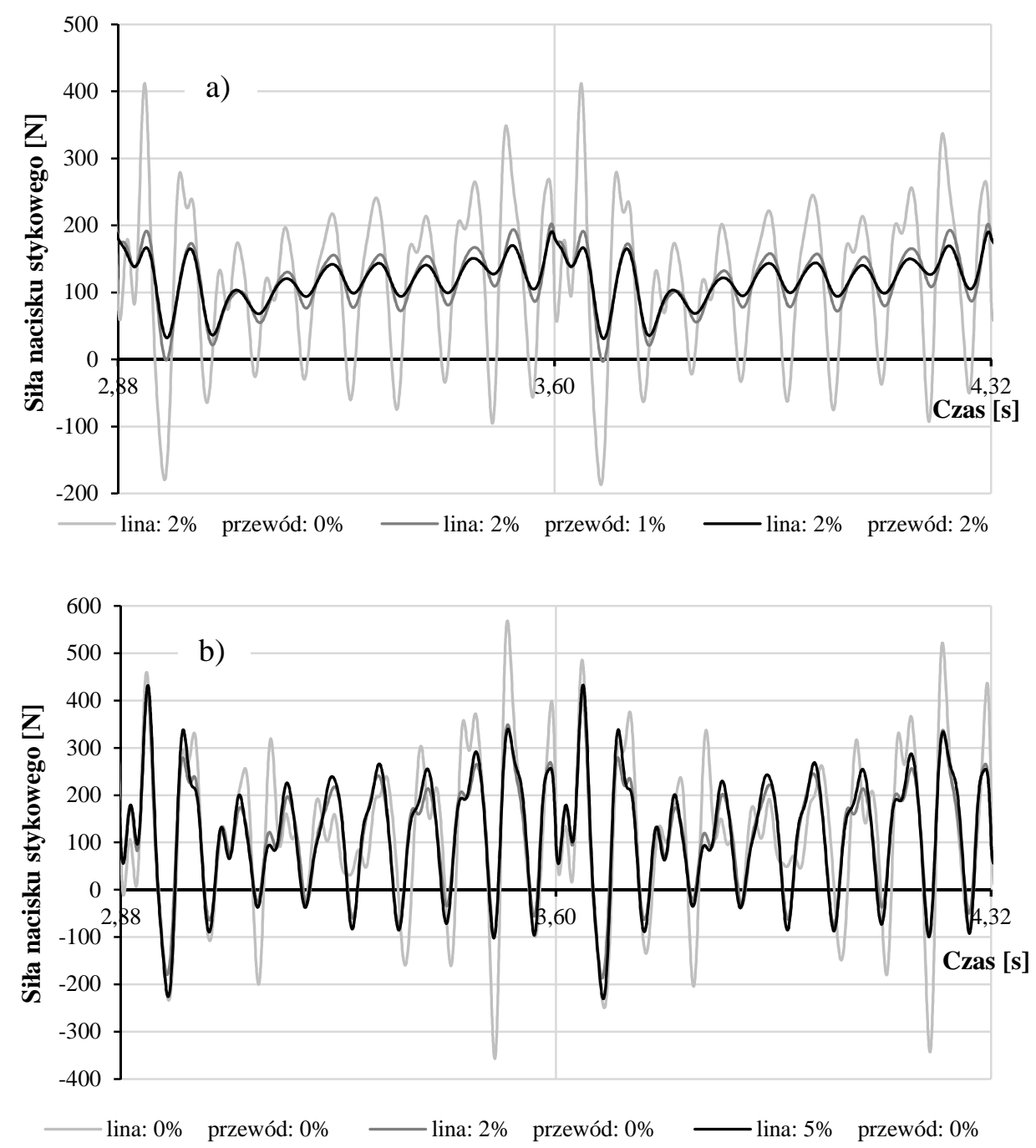

Rys. 3. Zmiany siły nacisku stykowego w czasie przejazdu pantografu przez piąte i szóste przęsło, w zależności od liczby tłumienia: a) przewodu jezdnego, przy stałej liczbie tłumienia liny nośnej, b) liny nośnej, przy pominięciu tłumienia w przewodzie jezdnym

Fig. 3. In-time variation of the contact force when the pantograph moves along the fifth and sixth span, depending on damping coefficient to critical of: a) the contact wire (damping in carrying rope is constant), b) the carrying rope (damping in contact wire is neglected) 

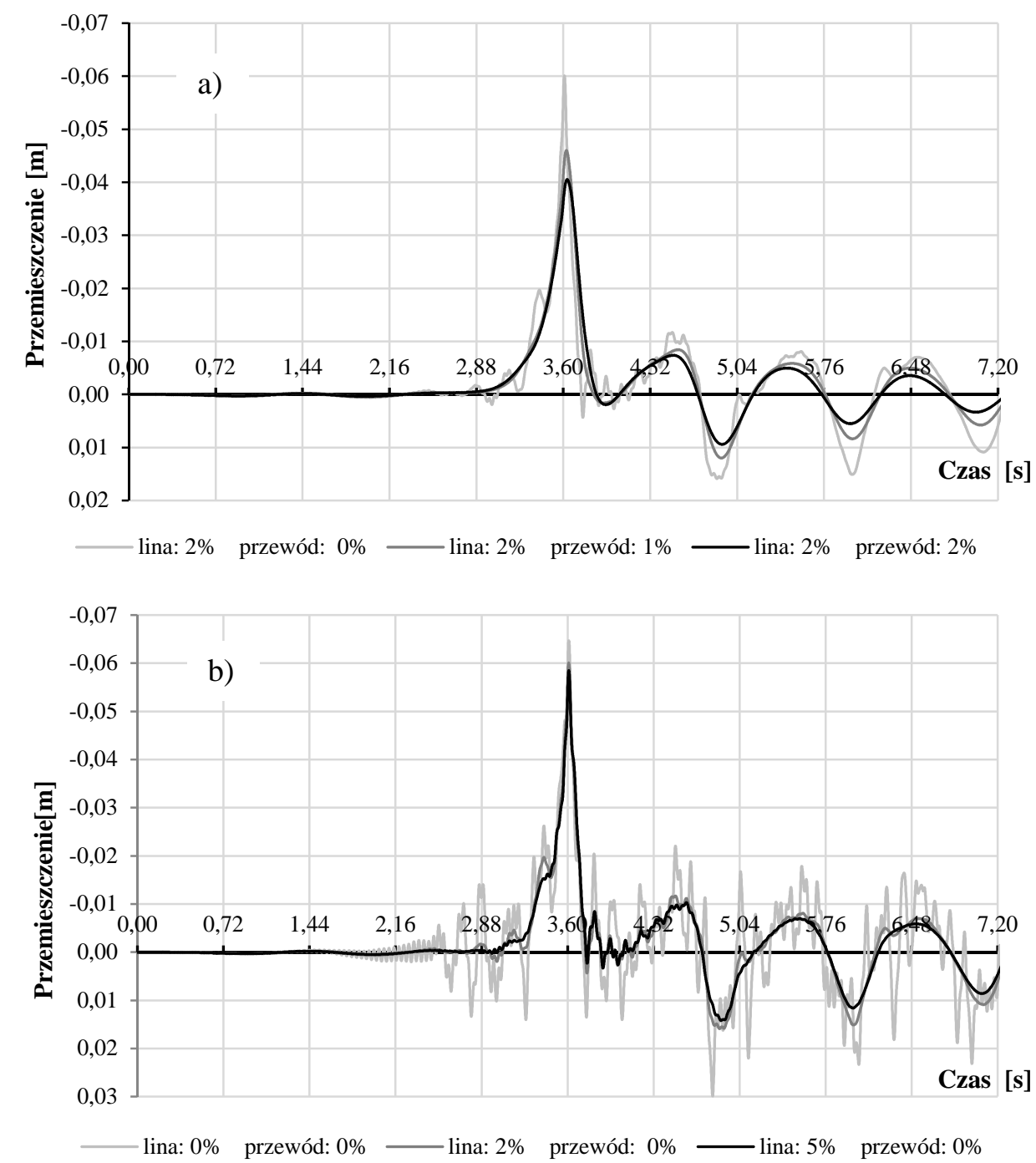

Rys. 4. Drgania przewodu jezdnego na środkowym wsporniku sieci (między przęsłem piątym i szóstym), w zależności od liczby tłumienia: a) przewodu jezdnego, przy stałej liczbie tłumienia liny nośnej, b) liny nośnej, przy pominięciu tłumienia w przewodzie jezdnym

Fig. 4. Vibrations of the contact wire at the central support of overhead wire system (between the fifth and sixth span), depending on damping coefficient to critical of: a) the contact wire (damping in carrying rope is constant), b) the carrying rope (damping in contact wire is neglected)

Przed przystąpieniem do właściwych obliczeń mających na celu analizę wpływu tłumienia w materiale liny nośnej i przewodu jezdnego, wykonano testy algorytmu obliczeniowego polegające na analizie zbieżności rozwiązań. Warian- 
towano liczbę funkcji bazowych ( $n$ ) zastosowanych do aproksymacji przemieszczeń pionowych i poziomych liny nośnej i pionowych przemieszczeń przewodu jezdnego, w obrębie jednego przęsła (łącznie $3 n$ ). Całkowita liczba funkcji aproksymacyjnych (sinusowych) wynosi $3 n \times$ liczba przęseł. Jest to równocześnie liczba współrzędnych uogólnionych określających stan przemieszczenia sieci trakcyjnej. W obliczeniach wariantowano też długość kroku numerycznego całkowania równań ruchu, przyjmując kolejno: 0,001 s, 0,0001 s i 0,00001 s. Na podstawie tych testów przyjęto do obliczeń krok 0,001 s, przy liczbie funkcji bazowych $n=20$.

Na rys. 3 przedstawiono fragmenty przebiegów zmian w czasie siły nacisku stykowego, odpowiadające przejazdowi pantografu przez przęsło piąte i szóste. Przebiegi na rys. 3 a wygenerowano przy różnych poziomach tłumienia w materiale przewodu jezdnego, przy stałym tłumieniu w linie nośnej $\alpha_{\mathrm{c}}=2 \%$. Natomiast na rys. $3 \mathrm{~b}$ jest wariantowane tłumienie $\mathrm{w}$ linie nośnej przy pominięciu tłumienia w przewodzie jezdnym. Analogiczne rozwiązania, ale dotyczące drgań przewodu jezdnego na wsporniku sieci, pokazano na rys. 4, na którym ujemnie jest znakowane uniesienie przewodu. Przedstawione symulacje drgań przewodu obejmują całkowity czas przejazdu pantografu przez sieć jezdną i odnoszą się do wspornika środkowego, znajdującego się między przęsłem piątym i szóstym.
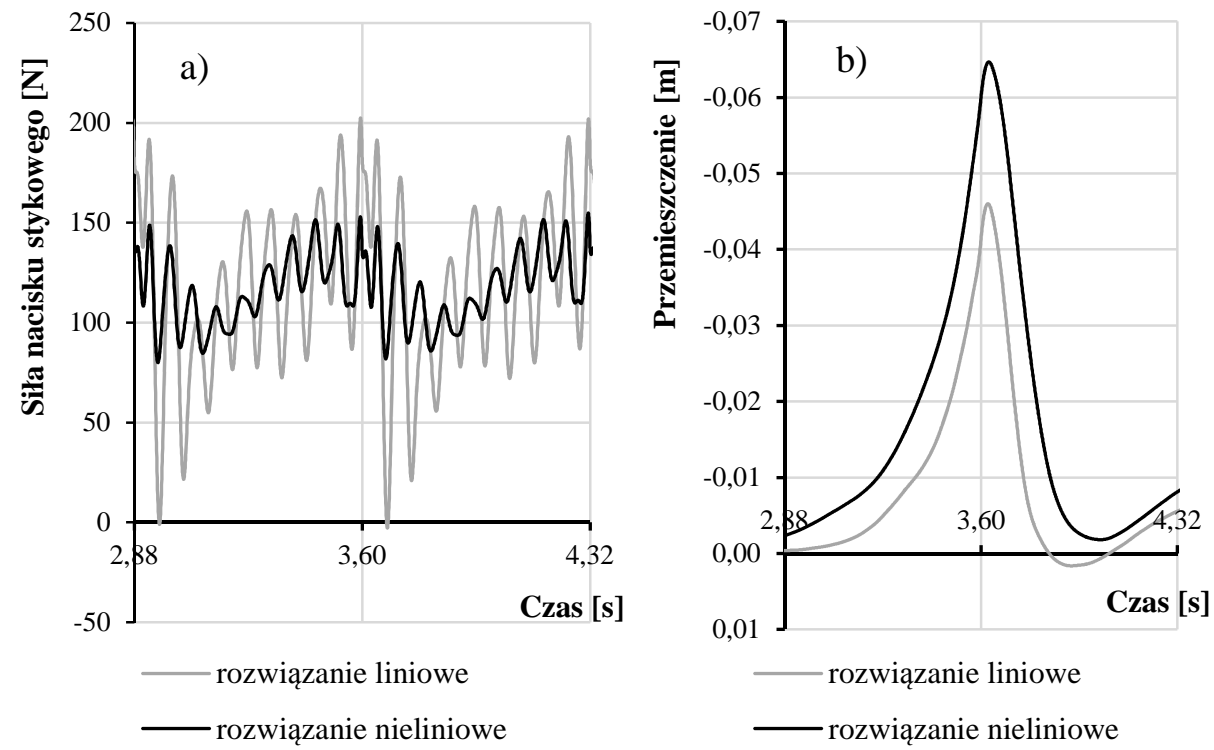

Rys. 5. Zmiany siły nacisku stykowego (a) i uniesienia przewodu jezdnego na środkowym wsporniku sieci (b), w czasie przejazdu pantografu przez dwa środkowe przęsła, w zależności od sposobu modelowania wieszaków

Fig. 5. In-time variation of the contact force (a) and contact wire uplift at central support (b), when the pantograph moves along two central spans, depending on the method of modeling droppers 
Na ostatnim rysunku (rys. 5) porównano przebiegi czasowe zmian siły nacisku stykowego w piątym i szóstym przęśle oraz uniesienia przewodu jezdnego na środkowym wsporniku badanej sekcji sieci, wyznaczone w zagadnieniu liniowym i nieliniowym, tzn. gdy wieszaki są typu prętowego (przenoszą siły rozciągające i ściskające) i typu przewodowego (przenoszą tylko rozciąganie). Obliczenia dotyczą przypadku, gdy $\alpha_{\mathrm{c}}=2 \%$ i $\alpha_{\mathrm{p}}=1 \%$.

\section{Analiza wyników i podsumowanie}

Analiza wykresów przedstawionych na rys. 3 i 4 prowadzi do kilku interesujących wniosków. Pierwszy z nich dotyczy wpływu tłumienia na siłę nacisku stykowego (siłę kontaktową). Widać, że tłumienie związane $\mathrm{z}$ materiałem liny nośnej, nawet rzędu 5\%, ma mały wpływ na lokalne amplitudy oscylacji, chociaż powoduje wyraźne zmniejszenie pików największych (rys. 3b). Znacznie większy wpływ na siłę kontaktową ma tłumienie materiałowe w przewodzie jezdnym. Nawet niewielkie tłumienie, jednoprocentowe, powoduje zasadnicze zmniejszenie lokalnych amplitud (rys. 3a). Siła kontaktowa oscyluje, ale prawie nie przyjmuje wartości ujemnych, które skutkują utratą kontaktu między nakładką ślizgacza pantografu i przewodem jezdnym (por. rys. 2) - a w konsekwencji pogorszeniem jakości odbioru prądu. Tłumienie materiałowe w przewodzie jezdnym wpływa też korzystnie na drgania przewodu - powoduje znaczące zmniejszenie maksymalnego uniesienia przewodu na wsporniku sieci i wygasza oscylacje wysokoczęstotliwościowe (rys. 4), w odróżnieniu od tłumienia związanego z liną nośną. Stąd wynika ważny wniosek praktyczny: poziom tłumienia drgań sieci trakcyjnych słabo zależy od cech materiałowych liny nośnej.

Kolejny wniosek dotyczy wymaganego poziomu tłumienia. W publikacji [3] podano, że sieci trakcyjne charakteryzują się niskim tłumieniem - rzędu $1 \%$. Na podstawie przedstawionych wyników badań można stwierdzić, że taki poziom tłumienia jest wystarczający, aby oddziaływania dynamiczne między pantografem i siecią jezdną nie powodowały istotnego pogorszenia jakości odbioru prądu, pod warunkiem, że tłumienie to wynika głównie z cech materiałowych przewodu jezdnego.

Instalowanie w sieciach trakcyjnych wieszaków typu przewodowego, wyłączających się przy ściskaniu, jest zabiegiem znacznie poprawiającym warunki odbioru prądu. To stwierdzenie wynika wprost $\mathrm{z}$ analizy wykresów pokazanych na rys. 5a. Przebieg zmian siły kontaktowej, wyznaczony jako rozwiązanie nieliniowe (tj. z uwzględnieniem faktu wyłączania się wieszaków), jest znacząco korzystniejszy od rozwiązania liniowego. Oscylacje są dużo mniejsze, zasadniczo maleją piki największe, pojawiające się po przejeździe pantografu przez wspornik sieci. Niestety, równocześnie rośnie znacząco maksymalne uniesienie przewodu na wsporniku sieci, co nie jest korzystne (rys. 5b). Przedstawione wyniki mają tylko wstępny charakter, ponieważ w obliczeniach ograniczono do jednej liczbę iteracji sił kompensujących wpływ wieszaków ściskanych (por. 
wzór (6)). Można się spodziewać, że zwiększenie liczby iteracji spowoduje zmniejszenie różnicy między rozwiązaniem liniowym i nieliniowym. Problem ten będzie przedmiotem dalszych badań.

Przedstawione wyniki analiz numerycznych świadczą o przydatności zaproponowanej metody symulacji do oceny drgań górnej sieci jezdnej, pantografów i siły kontaktowej. Uzyskane wyniki, dotyczące tzw. modelu odniesienia określonego normą europejską EN 50318: 2002 [13], mieszczą się w granicach określonych przepisami tej normy, co z kolei dowodzi poprawności metody. Metoda symulacji będzie nadal testowana w zakresie rozwiązań uwzględniających nieliniowe zachowanie wieszaków. Będzie też rozwijana w kierunku sugerowanym w pracy [11], poprzez wprowadzenie wymuszenia kinematycznego drgań pantografu spowodowanego drganiami pojazdu przejeżdżającego przez nierówność progową toru.

\section{Literatura}

[1] Dyrektywa 2008/57/WE Parlamentu Europejskiego i Rady w sprawie interoperacyjności systemu kolei we Wspólnocie.

[2] Bryja D., Prokopowicz D.: Dyskretno-ciągły model obliczeniowy sprzężonego układu dynamicznego: pantograf - napowietrzna sieć trakcyjna, Przegląd Komunikacyjny, r. 71, nr 5, 2016, s. 44-51.

[3] Poetsch G., Evans J., Meisinger R., Kortüm W., Baldauf W., Veitl A., Wallaschek J.: Pantograph/Catenary Dynamics and Control, Vehicle System Dynamics, no. 28, 1997, pp. 159-195.

[4] Wu T. X., Brennan M. J.: Basic Analytical study of pantograph-catenary system dynamics, Vehicle System Dynamics, no. 30, 1998, pp. 443-456.

[5] Wu T. X., Brennan M. J.: Dynamic stiffness of a railway overhead wire system and its effect on pantograph-catenary system dynamics, Journal of Sound and Vibration, no. 219,1999 , pp. $483-502$.

[6] Park T. J., Han C. S., Jang J. H.: Dynamic sensitivity analysis for the pantograph of a high-speed rail vehicle, Journal of Sound and Vibrations, no. 266, 2003, pp. 235-260.

[7] Lopez-Garcia O., Carnicero A., Marono J. L.: Influence of stiffness and contact modelling on catenary-pantograph system dynamics, Journal of Sound and Vibration, no. 299, 2007, pp. 806-821.

[8] Arnold M., Simeon B.: Pantograph and catenary dynamics: A benchmark problem and its numerical solution, Applied Numerical Mathematics, no. 34, 2000, pp. 345-362.

[9] Cho Y. H.: Numerical simulation of the dynamic responses of railway overhead contact lines to a moving pantograph, considering a nonlinear dropper, Journal of Sound and Vibration, no. 315, 2008, pp. 433-454.

[10] Rauter F. G., Pombo J., Ambrósio J., Chalansonnet J., Bobillot A., Pereira M. S.: Contact model for the pantograph-catenary interaction, Journal of System Design and Dynamics, vol. 1, no. 3, 2007, pp. 447-457.

[11] Pombo J., Ambrósio J.: Environmental and track perturbations on multiple pantograph interaction with catenaries in high-speed trains, Computers and Structures, no. 124,2013 , pp. 88-101. 
[12] Massat J.-P., Laurent C., Bianchi J.-P., Balmès E.: Pantograph catenary dynamic optimization based on advanced multibody and finite element co-simulation tools, Vehicle System Dynamics, vol. 52, Supplement, 2014, pp. 338-354.

[13] Norma EN 50318: 2002 ,Zastosowania kolejowe - Systemy odbioru prądu - Walidacja symulacji oddziaływania dynamicznego pomiędzy pantografem a siecią jezdną górną".

\section{VIBRATION ANALYSIS OF SUSPENDED CABLE STRUCTURE AS A MODEL OF RAILWAY OVERHEAD WIRE SYSTEM SUBJECTED TO MOVING PANTOGRAPHS}

\section{S u m m a r y}

Increasing train speeds and rapid development of high speed railway systems give rice to growing interest in dynamics of railway overhead wire systems. In recent years, many new publications on advanced numerical methods for computer simulation of vibration of pantographcatenary systems appeared in foreign literature. In Poland, this topic is relatively unknown, hence one of the objectives of this paper is to review the literature on methods for modeling overhead contact lines and pantographs. The main goal is to present an original method for simulation of pantograph and catenary coupled system vibration and the use of method in dynamic analysis of a sample system. The method is based on the computational model which have been presented in a separate article. This model is formulated on the basis of vibration theory of a continuous cable. Catenary is treated as initially tensioned, multi-span cable structure which consists of a carrying cable characterized by non-negligible static sag and a contact wire suspended by means of droppers. The slackening of droppers under compressive forces is taken into account. Catenary is subjected to a passage of two pantographs moving with constant sped, each idealized as twodegree-of-freedom dynamic system.

Equations of motion of the system, derived by the use of Lagrange equations and Ritz approximation of catenary displacements, are reexpressed in this paper to extract nonlinear forces which compensate the effects of compressed droppers. The method for solving nonlinear equations of motion is described. It is also explained what is a physical meaning of linear equations associated with these nonlinear. Exemplary simulations are presented for the catenary consisting of ten spans in order to demonstrate efficiency and computing capabilities of the simulation method. An influence of the material damping in carrying rope and this in contact wire, on the dynamic response of analyzed catenary is examined.

Keywords: vibration simulations, linear vibrations, nonlinear vibrations, contact force, contact wire vibrations, damping influence

Przestano do redakcji: 20.02 .2017 r.

Przyjęto do druku: 28.04.2017 r. 